Rok XIV (2019) | 2 (28) | s. 147-164

https://doi.org/10.12797/LV.14.2019.28.10

Wojciech Chlebda $\bullet$

Uniwersytet Opolski, Opole

womich4@wp.pl

\title{
O WYZWANIACH I ZADANIACH PAMIĘCIOZNAWSTWA LINGWISTYYZNEGO
}

Słowa klucze: pamięć osobnicza, pamięć zbiorowa, język, ujęzykowienie, etnolingwistyka, tożsamość, pamięcioznawstwo lingwistyczne

Keywords: individual memory, collective memory, language, linguification, ethnolinguistics, identity, linguistic memory research

Etnolingwistyka, której korzenie sięgają w Polsce pokładów dialektologii i folklorystyki, postawiła za cel swych penetracji ustalanie dróg i mechanizmów, dzięki którym w języku etnicznym odkłada świadectwa swego istnienia kultura ${ }^{1}$; rekonstrukcja tych świadectw pod postacią językowego (resp. językowo-kulturowego) obrazu świata jest podstawowym zadaniem etnolingwistów. Ale zawartość kręgu zagadnień, których w procesach owych rekonstrukcji dotykają etnolingwiści - kultura etniczna, interpretacja jej świata materialnego i duchowego, przeszłości i teraźniejszości - siłą rzeczy doprowadziła do styku etnolingwistyki z kręgiem nauk zorientowanych antropologicznie: kulturoznawstwem, antropologią, psychologią społeczną, socjologią wiedzy, historiografią, naukami o tożsamościach zbiorowych. Ich splot z etnolingwistyką jest tak organiczny, że zasadne wydało mi się postawienie pytania, czy etnolingwistyka może odgrywać wręcz rolę „zwornika nauk humanistycznych” (Chlebda 2012a).

1 Szerzej o korzeniach i dzisiejszym statusie etnolingwistyki piszę w obszernym wprowadzeniu do tomu Etnolingwistyka a leksykografia (Chlebda 2010). 
Skoro określamy dzisiaj etnolingwistykę - zwłaszcza od XIV Międzynarodowego Kongresu Slawistów w Ochrydzie (zob. Bartmiński, Chlebda 2008) - mianem „jednej z nauk o tożsamościach zbiorowych”2, prędzej czy później musiała się w orbicie jej zainteresowań pojawić także problematyka pamięci zbiorowej, uważanej wszak za fundament i spoiwo tożsamości wspólnotowych. Tak też się stało, a kiedy na naszych oczach poczęła się kształtować nowa subdyscyplina językoznawstwa, nazywana to lingwistyką pamięci, to pamięciologią, to pamięcioznawstwem lingwistycznym ${ }^{3}$, było jasne, że oba te nurty badań - etnolingwistyczny i pamięcioznawczy, oba z zapleczem tożsamościowym - prędzej czy później zetkną się z sobą: zderzą się lub wyjdą sobie naprzeciw.

Na tle etnolingwistyki - dyscypliny wciąż młodej, ale mającej już jednak za sobą 40 lat tradycji - pamięcioznawstwo lingwistyczne znajduje się w stanie wręcz niemowlęcym, tym bardziej jednak warto, jak sądzę, nakreślić pola jego faktycznych i potencjalnych działań, a zwłaszcza punkty i płaszczyzny jego styku z pokrewną mu przecież etnolingwistyką; może to przysłużyć się precyzowaniu ich profili, obszarów i celów, tych zwłaszcza, w których moce poznawcze obu tych dyscyplin mogą się wzajemnie dopełniać i wzmacniać. W niniejszym tekście chciałbym odpowiedzieć na trzy pytania: I. dlaczego etnolingwistyka może (jeśli wręcz nie powinna) włączyć do pola swych zainteresowań także relacje języka i pamięci, II. jakie są owe miejsca styczne języka i pamięci (czyli co usprawiedliwia próby powołania do życia subdyscypliny nazywanej pamięcioznawstwem lingwistycznym ${ }^{4}$ ), wreszcie III. gdzie interesy pamięcioznawstwa lingwistycznego i etnolingwistyki przecinają się najwyraźniej ${ }^{5}$.

2 Por.: „Etnolingwistyka, której zadaniem jest rekonstrukcja językowego obrazu świata, jest równocześnie - obok psychologii społecznej, psychologii świadomości, socjologii wiedzy, socjologii pamięci czy historiografii - nauką o tożsamościach zbiorowych, o narracjach interpretujących rzeczywistość" (Niebrzegowska-Bartmińska 2017: 11-12). Ten wymiar etnolingwistyki przeanalizowała w wymiarze praktycznym (i w ujęciu historycznym) Aleksandra Niewiara (2009).

3 Termin „lingwistyka pamięci” wprowadził w programowej dla omawianej subdyscypliny monografii zbiorowej Waldemar Czachur (zob. Czachur 2018), niestroniący zresztą i od nazwy „pamięciologia". Ponieważ punktem wyjścia moich refleksji nad związkami pamięci i języka było pamięcioznawstwo, wolę używać terminu „pamięcioznawstwo lingwistyczne”. Z kolei termin „pamięcioznawstwo” wprowadziły do naszego systemu terminologicznego Kornelia Kończal i Joanna Wawrzyniak (zob. Kończal, Wawrzyniak 2011).

4 Pytanie to jest tym bardziej zasadne, że chociaż związek pamięci i języka jest dla badaczy pamięci zwykle oczywisty, w pracach pamięcioznawczych językowy i językoznawczy aspekt pamięci i badań nad pamięcią jest z reguły pomijany. Symptomatyczne, że podstawowe dziś w Polsce kompendium wiedzy pamięcioznawczej, jakim jest leksykon kultury pamięci Modi memorandi (Saryusz-Wolska, Traba 2014), w ogóle nie zawiera haseł „język” czy „ujęzykowienie”. Także inne kompendium - Kultura pamięci Astrid Erll (2018) - językową stronę pamięci niemal całkowicie pomija (przy jednoczesnych odwołaniach do oralności, roli schematów narracyjnych czy metafor); wyraz lingwista pojawia się w tym cennym opracowaniu tylko raz.

5 Moją legitymacją do wypowiadania się na ten temat jest $\mathrm{z}$ jednej strony wieloletnia już praca w gronie badaczy tzw. lubelskiej szkoły etnolingwistycznej, z drugiej - rozciągnięta w czasie seria 
I. Związki pamięci zbiorowej z polem badawczym etnolingwistyki są wielorakie i w zasadzie dość oczywiste, niewymagające rozwiniętych uzasadnień. Na pytanie, dlaczego etnolingwiści mogą, a nawet powinni się zajmować także problemami pamięci zbiorowej, najkrócej można odpowiedzieć tak.

Po pierwsze, dlatego, że pamięć należy do tych obiektów rzeczywistości, które mają swój odłożony w języku obraz czy portret, który to obraz daje się złożyć na podstawie cząstkowych danych językowych metodami wypracowanymi w łonie etnolingwistyki. Dyscyplina ta odtwarzała językowo-kulturowe obrazy nie tylko obiektów fizycznych, jak miedza, księżyc, tęcza, koń, ale także obiektów abstrakcyjnych czy mentalnych, jak czas, honor czy wolność. Skoro tak, to dlaczego nie miałaby odtworzyć językowego obrazu pamięci, zwłaszcza że jest ona na dodatek zjawiskiem o wyjątkowej relewancji społecznej? Ta rekonstrukcja już się zresztą rozpoczęła: w pracach Anny Pajdzińskiej z początku XXI w. (Pajdzińska 2004, 2007, Pajdzin'ska 2005) czy moich nieco późniejszych (Chlebda 2011). Jeśli etnolingwistyka pomaga przy tym w odtwarzaniu reguł „nauk naiwnych” w rozumieniu Jurija Apresjana (zob. Apresjan 1994) - naiwnej fizyki, naiwnej medycyny, naiwnej astronomii, naiwnej lingwistyki ${ }^{6}$ - to można założyć, że w języku są zawarte także reguły „naiwnego pamięcioznawstwa”, które czekają tylko na swego odkrywcę. To pierwszy powód, by etnolingwiści zajęli się także pamięcią, a jednocześnie i pierwsze $\mathrm{z}$ wyzwań stojących tu przed etnolingwistyką.

Po drugie, pamięć zbiorowa (społeczna, wspólnotowa) należy do tych fundamentalnych konstruktów mentalnych, w których jak w soczewce zbiera się i uwidocznia stosunek danej wspólnoty etniczno-kulturowej do tych czy innych obszarów rzeczywistości - w tym wypadku do przeszłości (najczęściej własnej), do dziejów, do historii. Pamięć jest zbiorowym interpretantem tego właśnie „przeszłościowego” fragmentu świata. Jeśli mówimy, że językowo-kulturowy obraz świata (JOS w powszechnie stosowanym skrócie) jest zbiorem podmiotowych interpretacji różnych

tekstów, z których pierwszy powstał ponad 20 lat temu, a, rysując ramy tzw. geografii mentalnej, mówił w istocie o ramach polskiej pamięci/niepamięci zbiorowej (Chlebda 1997, także 2002). W innych tekstach tej serii, które były poświęcone tzw. mapom mentalnym, o pamięci/niepamięci mówiłem już wprost, pisząc o problemach jej „mapowania” (kartografowania; zob. np. Chlebda 2012b, 2014). Wreszcie w roku 2018 wygłosiłem trzy referaty, w których poruszałem kwestie relacji między językiem i pamięcią, używając już określenia „pamięcioznawstwo lingwistyczne”; pierwszy (Jak historia odkłada się w pamięci, jak pamięć odkłada się w języku) wybrzmiał na XVI Kongresie Slawistów w Belgradzie, a ukazał się w 31 tomie „Etnolingwistyki” (Chlebda 2019), drugi (Z katalogu zadań pamięcioznawczych) wygłosiłem na konferencji „Pamięć i styl” w Opolu (ukaże się w 28 tomie „Stylistyki”; Chlebda, w druku), trzeci - Jaki język? Jaka pamięć? - został przedstawiony na kolokwium pamięciologicznym w Uniwersytecie Warszawskim, które odbywało się pod hasłem „Pamięć w ujęciu lingwistycznym. Multimodalne ramowanie pamięci”; niniejszy tekst jest jego dalece zmodyfikowaną wersją.

6 Zręby naiwnej lingwistyki rekonstruuje np. praca Maćkiewicz 1999, naiwnej medycyny - Marczewska 2012. 
wycinków rzeczywistości, to inną taką zbiorową podmiotową interpretacją rzeczywistości jest pamięć. Pamięć i JOS stoją obok siebie w funkcji interpretowania wielorako złożonego świata i dystrybuowania tych interpretacji wśród członków danej wspólnoty. Mechanizmy tej interpretacji i dystrybucji są w wypadku JOS i pamięci miejscami zbieżne, miejscami rozbieżne, JOS i pamięć nie są tym samym, a ustalenie relacji między językowym obrazem świata i pamięcią wspólnotową jako dwoma konstruktami społecznymi jest kolejnym frapującym wyzwaniem badawczym. Teraz jednak poprzestańmy na stwierdzeniu, że konstrukt mentalny zwany pamięcią zbiorową stoi w tym samym szeregu zjawisk co konstrukt mentalny zwany językowym obrazem świata - i to już wystarcza, by etnolingwiści zainteresowali się także pamięcią. Uprzedzając dalsze rozważania, dodam, że kolejnym konstruktem w tym szeregu jest wiedza wspólnotowa - wiedza jako taka i wiedza szczegółowa, którą w odniesieniu do przeszłości jest zwłaszcza historiografia i archeologia teoretyczna?

Po trzecie, jak już wspomniałem, pamięć zbiorowa uważana jest powszechnie za jeden z warunków tożsamości. Mówi się ${ }^{8}$, że tożsamość grupowa nie istnieje bez pamięci historycznej danej grupy, bo to pamięć zapewnia członkom tej grupy poczucie ciągłości wspólnotowego trwania w czasie, czyli właśnie poczucie ich tożsamości. Etnolingwistyka z kolei jest, jak już zostało powiedziane, jedną z nauk o tożsamościach etniczno-kulturowych, czego wyrazem był wspólny i w pewnym sensie programowy (dla etnolingwistyki) referat Jerzego Bartmińskiego i Wojciecha Chlebdy na Kongresie Slawistów w Ochrydzie, rozpoczynający się w wersji drukowanej od znamiennych słów:

Badania etnolingwistyczne, w których obrębie pozostajemy, są z samej swojej istoty badaniami tożsamościowymi, ściślej - badaniami nad tożsamością wspólnotową, zwłaszcza narodową (choć nie tylko). Wynika to z faktu, że, z jednej strony, sama tożsamość wspólnotowa jest wielorako ujęzykowiona, z drugiej zaś - że badania etnolingwistyczne stawiają sobie za cel główny docieranie do takich fenomenów, które, postrzegane całościowo, określamy właśnie jako tożsamość wspólnotową, zbiorową. Teza ta oznacza, że badacz danej problematyki powinien, po pierwsze, dążyć do ustalenia, z jakich to mianowicie fenomenów językowych złożona jest tożsamość wspólnotowa, po drugie zaś, jakimi metodami i na podstawie jakich danych źródłowych

7 Archeologia, w rozumieniu potocznym polegająca na przeprowadzaniu wykopalisk, wydobywaniu z ziemi historycznych artefaktów i ich datowaniu, jest w istocie nauką, która zajmuje się interpretowaniem przeszłości, tworzeniem jej podmiotowych wyobrażeń czy obrazów - podobnie jak czyni to historiografia czy właśnie (w wybranym obszarze rzeczywistości, jaki tworzą zdarzenia minione) etnolingwistyka. Takie rozumienie archeologii zostało zaprezentowane w fundamentalnej pracy zbiorowej Przeszłość społeczna. Próba konceptualizacji (Tabaczyński i in. 2012).

8 Związek pamięci wspólnotowej z tożsamością zbiorową należy do ugruntowanych przekonań wspólnotowych, w zasadzie niewymagających dowodzenia, choć obudowany jest ogromną literaturą przedmiotu. Skrótowe, ale trafne uwagi na ten temat sformułowali Katarzyna Growiec i Sławomir Kapralski, autorzy artykułu hasłowego Tożsamość w leksykonie Modi memorandi (Saryusz-Wolska, Traba 2014: 489-496). 
cechy tożsamości wspólnotowej rekonstruować i wiarygodność tych rekonstrukcji potwierdzać (Bartmiński, Chlebda 2008: 11-12).

Jeżeli więc, ujmując rzecz najkrócej, etnolingwistyka zajmuje się również tożsamościami, a pamięć jest fundamentem tożsamości, to etnolingwistyka po prostu nie może się pamięcią wspólnotową nie zajmować.

II. Przechodząc z kolei do pytań o miejsca styczne pamięci i języka, zrelacjonuję pokrótce swoje ustalenia, najpełniej wyrażone w dwóch tekstach o znaczących tytułach: Pamięć ujęzykowiona9 (Chlebda 2012b) oraz Pamięć i język. Zarys relacji (Chlebda 2018a).

Aby mówić o związkach pamięci i języka, trzeba najpierw dokonać rozwarstwienia pojęcia pamięci i wyróżnić w nim co najmniej trzy poziomy:

1. pamięć in se, pewną osobistą substancję psychiczną, niedostępną dla zewnętrznego obserwatora;

2. pamięć, czyli autorelację (i autorelacje) o treści czy zawartości pamięci in se wciąż na poziomie osobniczym, ale już w postaci uzewnętrznionej przez podmiot pamięci;

3. pamięć ${ }_{2}$, czyli pochodne (wtórne) relacje o treści czy zawartości pamięci in se już na poziomie ponadjednostkowym, interakcyjnym, wspólnotowym.

Zasadnicza cezura oddziela pamięć in se (uwewnętrznioną, a więc niedostępną dla zewnętrznego obserwatora) od pamięci (uzewnętrznionej); tym samym związek pamięci i języka zachodzi na dwóch płaszczyznach, wewnętrznej i zewnętrznej, a sama relacja między pamięcią i językiem jest dwuwektorowa. Zgodnie z wektorem dośrodkowym język uczestniczy w samym powstawaniu i formowaniu się pamięci osobniczej (pamięci in se), w segregacji i porządkowaniu dopływających do psychiki bodźców, wpływa kształtująco na samą treść pamięci i na stabilizację doznań w ramach pamięci; jak to trafnie określił Krzysztof Pomian, „język kształtuje [...] pamięć w samej jej treści, bo nastawia i ukierunkowuje postrzeganie oraz wpływa na zatrzymywanie danych, współdeterminując zatem ich uporządkowanie" (Pomian 2006: 146). Zgodnie natomiast $\mathrm{z}$ wektorem odśrodkowym język uczestniczy w materializowaniu (się) treści pamięci poza sferą psychiki osobniczej, w jej uzewnętrznianiu się i wchodzeniu w sferę relacji interpersonalnych (to przestrzeń pamięci i pamięci ${ }_{2}$ ).

9 „Ujęzykowiona” jedynie (a nie „językowa”), gdyż dopływające do naszej pamięci bodźce mają różną naturę - zapachową, dotykową, dźwiękową, smakową (przypomnijmy „smak proustowskiej magdalenki" - ciastka, które stało się symbolem wywoływania przeszłości z pamięci) - nie można więc sprowadzać pamięci tylko do języka. Jeśli jednak zakładamy, że język w utrwalaniu i porządkowaniu dopływających do naszej psychiki bodźców gra rolę decydującą, choć nie wyłączną, to można, jak sądzę, mówić, że „pamięć jest ujęzykowiona” (i to na różne sposoby); „ujęzykowienie pamięci” wydaje mi się określeniem najwłaściwszym. 
W wypadku pamięci mówię nie tylko o autorelacji (w liczbie pojedynczej), ale też o autorelacjach treści pamięci, bo dany człowiek może relacjonować zawartość swojej pamięci wielokrotnie, i to w sposób różny, dając odbiorcy swą własną relację relacje $e_{2}$, relacje $e_{n}$.W wypadku pamięci mamy do czynienia ze spotęgowaniem takich różnic, nierzadko też z zanikaniem elementów relacji sensu stricto na rzecz zwykłej nar racji, a następnie też na rzecz narracji o wcześniejszych innych narracjach. Nie ulega dla mnie wątpliwości, że między tymi trzema rodzajami pamięci (z których każdy jest nadto wielorako rozwarstwiony) istnieje, by tak rzec, postępujący rozziew treściowy, który, jak sądzę, można lingwistycznie sparametryzować.

Mówienie na ten temat jest bardzo utrudnione ze względu na brak odpowiedniego metajęzyka (np. brak ścisłych terminologicznych nazw dla wielu odmian pamięci $\mathrm{z}$ tych trzech poziomów $)^{10}$, niemniej wydaje się prawdopodobne, że, powtórzę, każda $\mathrm{z}$ tych trzech warstw pamięci ma własną charakterystykę językową i że mimo wspomnianych trudności da się ustalić ich językowe parametry. Językowej specyficzności warstwy pierwszej (pamięci in se) możemy się jedynie domyślać, skoro jest ona ściśle subiektywna - pewnie ma ta pamięć nielinearną składnię, pewnie elementy werbalne współwystępują w niej ze zmemoryzowanymi wrażeniami wizualnymi, taktylnymi, zapachowymi itp., pewnie jest to dopiero mało stabilny surowiec, z którego w międzyludzkich interakcjach formuje się linearny (narracyjny) kształt autorelacji werbalnej, przy czym autorelacja ta zwrotnie wpływa stabilizująco na zawartość pamięci in se. Niewiele na ten temat wiemy; rzecz wymagałaby analizy wielu tekstów o charakterze introspektywnym - czy to w literaturze pięknej, czy we wspomnieniowej - lub sięgnięcia po doświadczenia psychologii osobniczej, w tej ostatniej zaś wymagałaby też przeprowadzenia eksperymentów psycholingwistycznych.

Natomiast narracje, tworzące proces relacjonowania pamięci i pamięci, są nam dane, są dostępne obserwatorowi i jako takie mogą stanowić obiekt analizy - także lingwistycznej. Należy przy tym podkreślić, że autorelacje jednostkowe (pamięć) są fundamentem pamięci grupowej - rodzinnej, lokalnej, regionalnej; to od nich zaczyna się praktyczne uspołecznienie treści pamięci indywidualnej. Innymi słowy, jeśli między pamięcią indywidualną a grupową istnieje ciągłość, to zapewniają tę ciągłość wyłącznie narracje. Narracje zaś nie są względem treści pamięci pasywne czy neutralne. Od wyboru narracji zależy wprost obraz przeszłości. Jak w pracy Przedstawianie i narratywizm w archeologii dowodzi Arkadiusz Marciniak (2012), wybitny metodolog archeologii, za naturalną strukturę narracyjną tekstu o przeszłości uważa się powszechnie linearne całości narracyjne o charakterze opowieści „Z początkiem, środkiem i zakończeniem”. Istnieje jednak

10 Wypowiem tu na marginesie myśl bynajmniej nie marginalną, iż wśród powinności językoznawców widzę też dopełnienie i doprecyzowanie aparatu pojęciowo-terminologicznego zarówno pamięcioznawstwa lingwistycznego, jak i pamięcioznawstwa w ogóle. 
szereg odmiennych form narracji, które są nie tylko odmiennym sposobem pisania o przeszłości, ale same wytwarzają odmienną przeszłość. Należą do nich narracje okrężne, równoległe, spiralne, aforystyczne czy rozdwojone (ibid.: 164; podkr. - W.Ch.).

Przeświadczenie, że odmienne rodzaje narracji wytwarzają odmienne obrazy przeszłości (które zresztą przyjmujemy zwykle za samą przeszłość), cechuje się najwyższą relewancją nie tylko dla archeologa czy historiografa, ale też dla badacza pamięci, w tym - pamięciologa językoznawcy.

Jakakolwiek refleksja na temat uzewnętrzniania i postępującego uspołeczniania treści pamięci indywidualnej siłą rzeczy musi się odnieść do nurtu narratywistycznego, tj. do tradycji pytań o progi, pryzmaty czy filtry, przez które przechodzi doświadczenie przeszłości, by poprzez werbalizację zaistnieć i stać się faktem międzyludzkim, pytań o formujące oddziaływanie tych pryzmatów na werbalną postać doświadczenia, wreszcie o relację między zwerbalizowanymi postaciami (obrazami) tych doświadczeń a ich domniemanymi kształtami w samej rzeczywistości. Nie mam tu możliwości rozwijania tego wątku ${ }^{11}$, przypomnę jedynie, że narracje - jeśli rozumieć je stosunkowo wąsko, jako swego rodzaju „sprawozdania z treści pamięci" - to cały arsenał środków wyrażania, także gotowych (systemowych): środków gatunkowych, stylowych, dyskursowych, które podsuwają - czasem narzucają - zarówno ramy wypowiedzi (np. gatunkowe), jak i dobór środków leksykalnych, frazeologicznych, składniowych, które dla treści pamięci niosą, by tak rzec, społecznie usankcjonowane formy odlewnicze. Potrzebny jest tutaj swego rodzaju katalog takich form, werbalnych eksponentów pamięci, by najtrafniejsze nawet, ale formułowane w kategoriach ogólnych refleksje na temat pamięci wspólnotowej podbudować analizą substancjalną: analizą namacalnych, wymiernych form oferowanych pamięci przez twardą materię języka (i to, powtórzę, nie języka w ogóle, ale danego języka etnicznego) - od „twardych danych” niskiego szczebla (fonetycznych, morfologicznych, leksykalnych) po szczeble najwyższe, kategorialne: tekstowe, genologiczne, dyskursywne. Będzie o nich jeszcze mowa w dalszej części tego tekstu.

III. Teraz natomiast, zgodnie z zapowiedzią, przedstawię - z konieczności w zgrubnym, niekiedy wręcz szkicowym zarysie - dziesięć obszarów pamięci i pamięcioznawstwa, odnośnie do których językoznawca może się wypowiadać w sposób kompetentny, uzasadniony językową naturą badanej materii. Etnolingwistę zainteresują

11 To tradycja pytań stawianych przez Franka Ankersmita czy Haydena White’a, w Polsce m.in. przez Jerzego Topolskiego, Wojciecha Wrzesińskiego czy Jana Pomorskiego. Z braku miejsca nie odwołuję się tu do wielkiej literatury tego zagadnienia, syntetycznie zarysowanej przez Michała Pawła Markowskiego w Teoriach literatury XX wieku (Burzyńska, Markowski 2006: 497-517). W odniesieniu do dzisiejszych dyskursów polskich kwestie te naświetlił Jacek Wasilewski (2012); swoje stanowisko w tej materii przedstawiam w pracy: Chlebda 2019. 
przede wszystkim kwestie związane z pamięcią zbiorową (społeczną), ale warto pamiętać, że, jak już wspomniałem, pamięci wspólnotowej by nie było bez określonej mnogości pamięci indywidualnych, tych ostatnich nie można więc w badaniach ignorować, bo tworzą one sui generis substrat pamięci wspólnotowych. W zarysowanych przeze mnie obszarach są miejsca, w których interesy pamięcioznawstwa i etnolingwistyki krzyżują się czy nakładają - ale też pamięcioznawstwa lingwistycznego nie można sprowadzać wyłącznie do etnolingwistyki; ma ono także swoje niezależne interesy, z etnolingwistyką rozłączne lub związane z nią jedynie pośrednio.

1. Pierwszy obszar zagadnień obejmuje zjawiska, by tak rzec, wewnątrzjęzykowe, które jako takie właśnie, czyli pozostające w granicach samej materii języka, są zwykle rozpatrywane; to głównie leksykalizacja i frazeologizacja, a więc postępujące zacieranie się związku motywacyjnego między współczesnym znaczeniem realnym jednostek języka a pierwotnym znaczeniem strukturalnym fundowanym słowotwórczo i etymologicznie. Udział w tych procesach ma bez wątpienia czynnik upływu czasu, i ten w opisach procesów leksykalizacji czy frazeologizacji jest uwzględniany. Wydaje się natomiast, że opisów tych procesów dokonywano dotychczas poza kontekstem pamięcioznawczym, jakby nie dostrzegając, że zachodzą one $\mathrm{w}$ istocie $\mathrm{w}$ ramach procesów pamięciowych, zwłaszcza niepamiętania czy, ściślej, zapominania, zarówno jednostkowego, jak i społecznego. Przed etymologią, słowotwórstwem, leksykologią, frazeologią pamięcioznawstwo lingwistyczne zdaje się otwierać uzupełniającą perspektywę oglądu obiektów ich badań.

2. Drugi obszar zadań związany jest ze wspominanym wcześniej ustalaniem, wyodrębnianiem i klasyfikowaniem językowych eksponentów pamięci. Jak już mówiłem, w procesach relacjonowania zawartości pamięci (zarówno w autorelacjach, jak i w narracjach pochodnych) treść pamięci, materializując się, przybiera rozmaite formy językowe zwane przeze mnie eksponentami pamięci. Spektrum tych eksponentów jest olbrzymie - sięga od wykładników fonetycznych, morfologicznych, leksykalnych, składniowych po gatunki mowy, wielkie narracje, wielkie metafory, całe dyskursy memorialne ${ }^{12}$. Analiza powinna pokazać, które z nich wyspecjalizowały się w werbalizowaniu treści pamięciowych i stały się szczególnie „pamięcionośne”, a dla których ta funkcja jest fakultatywna. Bodaj najbardziej zapoznanym wymiarem języka jest w kontekście pamięci jego wymiar foniczny, dźwiękowy z jego prozodią, intonacjami, ze znaczącymi zmianami tembru, zawieszeniami głosu, pauzami hezytacyjnymi itd., wymiar dla komunikacji prymarny, gdy tymczasem badania języka pamięci skupiają się niemal wyłącznie na świadectwach (za)pisanych. Niejako z drugiej strony lokują się zjawiska wykraczające już poza obszar czystej werbal-

12 Dysponujemy cząstkowymi analizami takich eksponentów: dla przykładu Anna Ziębińska-Witek (2005: 37-50) dokonała przeglądu metafor, w których kategoriach materializuje się pamięć Holocaustu, Marta Wójcicka (2014, w druku) zaś skupiła swoją uwagę na relacjach między pamięcią zbiorową a wyspecjalizowanymi gatunkami tekstu. 
ności, choćby najszerzej pojmowanej: wszak obok języka w sensie lingwalnym (czy to pisanego, czy fonicznego) istnieje też język w sensie semiotycznym. Należy sobie uzmysłowić, że tak jak myśl ludzka w procesie jej kształtowania się nie tyle się werbalizuje, ile semiotyzuje - czyli szuka dla swego materialnego zaistnienia różnych form znakowych, form o różnej substancji (w tym lingwalnej, ale jako jednej z kilku) - tak też zapewne pamięć materializuje się i uzewnętrznia w formach dostarczanych przez oba języki, lingwalny i semiotyczny, wykorzystując prócz środków stricte werbalnych także parawerbalne, kinetyczne (w tym przebogate spektrum środków mimicznych, gestykalnych, taktylnych), środki proksemiczne, "gramatykę obrazów", organizowanie przestrzeni publicznej, modelowanie krajobrazu, tworzenie domen symbolicznych itd. Odnoszę wrażenie, że kiedy rozważa się relację "pamięć - język”, ma się na myśli głównie, jeśli nie wyłącznie, język lingwalny (werbalny). Udział znaków innych niż werbalne, szerzej: udział multimedialności, multikodalności i multimodalności $\mathrm{w}$ dwóch podstawowych tu procesach - w procesie formowania się pamięci in se oraz $\mathrm{w}$ procesie formułowania relacji o treści tej pamięci (resp. tworzenia narracji o zawartości pamięci) - jest słabo poznany (może najlepiej od strony, by tak rzec, finalnej: od strony upamiętnień, a więc semiotycznej organizacji przestrzeni publicznej, w tym muzealnej; na ten temat zob. np. Nijakowski 2006; Czerwiński 2015; Fabiszak, Brzezińska, Owsiński 2016; Ćwiek-Rogalska 2017; Fabiszak, Brzezińska 2018).

Na marginesie pytania o typ werbalności, jaki reprezentują językowe eksponenty pamięci, chcę przypomnieć, że język istnieje w kilku podstawowych postaciach: [1] jako abstrakcyjny system znaków i reguł ich konfigurowania; [2] jako międzyludzka praktyka komunikacyjna wraz z jej wytworami, tekstami i całymi dyskursami; [3] jako indywidualny, ale podzielany społecznie psychiczny zbiór kategorii językowo-myślowych modelujących relacje każdego człowieka z jego otoczeniem; [4] jako językowa świadomość wspólnotowa warunkująca poczucie tożsamości jednostki i grupy. Ten czworobok jest nierozerwalny, cztery jego boki wzajemnie się warunkują, więc jeśli mówimy o relacji języka i pamięci, to każdy z tych boków (wymiarów języka) na swój sposób wchodzi w relację czy reakcję z pamięcią. Jeśli przyjąć tę tezę, to rodzą się pytania: który wymiar języka z jakim wymiarem pamięci reaguje najefektywniej? Poprzez który wymiar języka jaki wymiar pamięci najskuteczniej się odsłania? Który wymiar języka jaki wymiar pamięci w sposób konieczny warunkuje? Odpowiedzi na te pytania są istotne także dlatego, że za każdy z tych czterech wymiarów języka czuje się odpowiedzialna inna wyspecjalizowana subdyscyplina językoznawstwa (a więc, w wielkim przybliżeniu, odpowiednio: 1. lingwistyka strukturalna, 2. teoria dyskursu i komunikacji interpersonalnej, 3. lingwistyka kognitywna i etnolingwistyka, wreszcie 4. psycholingwistyka i lingwistyka antropologiczna). Kiedy się więc zastanawiamy, jak zbliżyć lingwistykę do pamięcioznawstwa, należy też odpowiedzieć na pytanie, które jej subdyscypliny do jakich zadań angażować. 
3. Trzeci obszar zagadnień dotyczy pytania, co językowe eksponenty pamięci mówią o samej pamięci w dwóch jej głównych wymiarach: osobniczym i społecznym. Dla wymiaru osobniczego wybrałbym do analizy eksponenty związane $z$ brudnopisowymi prywatnymi zapiskami (z ich skreśleniami, poprawkami, glosami na marginesach i innymi świadectwami poszukiwań dla treści pamięci form najbardziej adekwatnych), dziennikami, pamiętnikami, z introspekcjami literackimi, także poetyckimi, które mogą wiele powiedzieć o pamięci jako psychicznym fenomenie ludzkim: o jej strukturze, mechanizmach gromadzenia bodźców, mechanizmach ich przechowywania, przetwarzania, przeszukiwania i ujawniania (także zatajania), utraty, czyli zapominania, o mechanizmach korzystania z pamięci w komunikacji itp. Dla wymiaru społecznego (ponadjednostkowego) analiza werbalnych eksponentów pamięci może być interesująca zwłaszcza w kontekście działań na języku mających na celu formowanie i deformowanie treści pamięci (aż po założenia tzw. polityki historycznej w wymiarze państwowym).

4. Czwarty obszar obejmuje kwestię etniczności (języka) pamięci, werbalne świadectwa zmian, jakie w pamięci osobniczej wywołuje przełączanie się z jednego kodu etnicznego na inny. Odwołam się w tym kontekście do rozmowy Wojciecha Orlińskiego z wybitnym architektem Danielem Libeskindem, którego międzynarodowa kariera rozpoczęła się od projektu Muzeum Żydowskiego w Berlinie. Rozmowa toczyła się w Warszawie na Złotej 44, w „Żaglu” Libeskinda, dotyczyła społecznych funkcji architektury i odbywała się w języku angielskim - aż do momentu, gdy Libeskind wspomniał, że czuje się emocjonalnie związany z Warszawą, a jego matka mieszkała tuż za rogiem. „Gdzie dokładnie?” - pyta Orliński i przed odpowiedzią pisze w nawiasie kursywą: „(Libeskind niespodziewanie przechodzi na język polski) - Ulica Twarda, numer piąty... Ja tam byłem niedawno". Po chwili milczenia obaj panowie podchodzą do okna, patrzą w stronę Twardej i wracają do rozmowy po angielsku (Orliński, Libeskind 2018). Zwraca tu uwagę fakt, że dopóki rozmowa toczy się na poziomie wied zy, jej językiem jest angielski. Gdy do rozmowy wdziera się pa mięć, wspomnienie matki i dzieciństwa, następuje przekodowanie $\mathrm{z}$ angielskiego na język tej pamięci - polski.

Przywołałem to zdarzenie, bo czytając jego opis, uświadomiłem sobie, że kiedy badacze rozważają związki pamięci i języka, z reguły mają na myśli „język w ogóle”, język jako taki, język ludzki czy naturalny. Natomiast etniczność języka - a zwłaszcza etniczność języka pamięci - schodzi na drugi-trzeci plan albo w ogóle nie dochodzi do głosu lub też uważana jest za coś zrozumiałego samo przez się. Tymczasem tak jak myślimy w konkretnym języku narodowym (zwykle macierzystym czy ojczystym), tak samo pamiętamy - w takim przynajmniej stopniu, w jakim zapamiętywanie, pamiętanie i pamięć są ujęzykowione - również w konkretnym języku narodowym. To jest czynnik wielkiej wagi, bo to nie język w ogóle, abstrakcyjny system znaków, ale właśnie dany język etniczny dostarcza takich, a nie innych form, 
matryc, schematów, wzorców, w które wlewa się treść pamięci i które lepią jej treść i profilują jej kształt.

Pod weryfikację przedkładam tezę, że dany język etniczny może wręcz sprzyjać zapamiętywaniu i wyrażaniu jednych treści - i nie sprzyjać zapamiętywaniu innych. Ku takiej tezie naprowadzają mnie spostrzeżenia badaczy relacji polsko-żydowskich, z których wynika, że język polski nie tylko na poziomie użycia, ale już w swoim wymiarze systemowym zdaje się podprowadzać swoich użytkowników ku myśleniu i działaniu w kategoriach piętnowania i wykluczania ${ }^{13}$. Tym samym zostaje nam przedłożona sugestia, że język - nasz język narodowy, nie język „w ogóle” - nieuchronnie popycha nas $\mathrm{w}$ stronę wykluczających interpretacji rzeczywistości, stanowiąc bez mała opresyjną instytucję kultury. Ale to właśnie ten nasz język - jeśli przyjąć tezę o ujęzykowieniu pamięci - jest podstawowym instrumentem naszego zapamiętywania i pamiętania. Jakie ma to skutki dla samego procesu zapamiętywania, dla selekcji dopuszczanych do pamięci bodźców i w rezultacie dla treści czy zawartości polskich pamięci wspólnotowych?

5. O ile wyżej mowa była o językach poszczególnych rodzajów pamięci (językach relacjonowania treści pamięci), piąty obszar zagadnień obejmuje to, co można by nazwać językiem naszego wypowiadania się o pamięci (w sytuacjach, gdy pamięć przestaje być przedmiotem relacjonowania $\mathrm{w}$ narracjach, a staje się obiektem charakteryzowania). Obszar ten skupia językowe sposoby radzenia sobie ludzi z fenomenem pamięci, próby ujmowania jej ulotnej substancji w bardziej twarde kategorie, myślenie i mówienie o pamięci np. przy użyciu metafor, metonimii, metaftonimii, synekdochy, i to w różnych typach dyskursu, różnych gatunkach i stylach wypowiedzi. Obszar ten wydaje się szczególnie bliski etnolingwistom. Wiele danych w tym zakresie przynosi praca Anny Pajdzińskiej Obraz pamięci w języku polskim (Pajdzin'ska 2005), w której obraz pamięci został zrekonstruowany na podstawie danych słownikowych. W mojej natomiast pracy Szkice do jezzykowego obrazu pamięci (Chlebda 2011) analiza oparta była na danych tekstowych z nowszej warstwy polszczyzny (z początku XXI w.); w jej wyniku okazało się, że w porównaniu z obrazem słownikowym tekstowy obraz pamięci jest odmienny: pamięć została w tych tekstach przez Polaków „odprywatniona”, „odpsychologizowana”, powiązana

13 Por. np.: „W świecie polskiej pamięci nie ma języka, którym można opowiedzieć o prześladowaniach Żydów z zewnątrz antysemickiego stereotypu z dystansem, pozwalającym zobaczyć, co się naprawdę dzieje” (Janicka, Żukowski 2016: 62); „Utrwalone w języku zwyczaje, schematy, wiążące się z danymi słowami konotacje umożliwiają czy też - w przypadkach najbardziej drastycznych wymuszają negatywny stosunek do innego człowieka, a więc nie tylko dopuszczają swoistą mowę nienawiści, ale ją w pewien sposób z góry zakładają" (Głowiński 1995: 40). Marcin Napiórkowski (Wężyk, Napiórkowski 2016: 18) dopuszcza myśl, że „być może nasz język pamięci ma tylko słownik mówiący o tym, że zawsze są jacyś oni, obcy, inni”, Andrzej Leder (2014: 50) zaś wysuwa przypuszczenie, że wstręt i pogarda względem Żydów są do dziś dnia czymś „głęboko tkwiącym w językowym porządku polszczyzny”. 
z kategoriami społecznymi, narodowymi, historycznymi; nowym zjawiskiem w polszczyźnie jest mówienie o pamięci w liczbie mnogiej (konflikt sąsiednich pamięci, zderzenie pamięci lokalnych, wspólnota polskich pamięci), a zjawiskiem szczególnie symptomatycznym jest nowa metaforyka: pamięć z pojemnika do przechowywania wspomnień staje się $\mathrm{w}$ polskich tekstach coraz bardziej materiałem budulcowym, który, jak pisałem, „można lepić, ugniatać, urabiać, kruszyć, zlepiać na nowo, z którego można tworzyć nowe obrazy minionego" (ibid.: 91). Wszystkie te informacje niesie wyłącznie leksykalna (kolokacyjna) warstwa tekstów polskich.

6. W obszarze szóstym umieściłbym analizę referencji wyrazu pamięć w różnych typach wypowiedzi. Na myśl o potrzebie takiej analizy naprowadziła mnie lektura specjalnego wydania „Tekstów Drugich” z roku 2016, wydanego pod hasłem „Polska pamięć". O pamięci piszą w nim literaci, literaturoznawcy, antropolodzy, filozofowie, socjologowie, historycy, psychologowie społeczni itp., z których wszyscy mówią o tytułowej „polskiej pamięci”, tyle że nawet pobieżna analiza kontekstów pokazuje, iż oprócz pamięci właściwej autorzy kryją pod wyrazem pamięć także zjawiska pokrewne i powinowate, ale z pamięcią bynajmniej nietożsame - używają wyrazu pamięć, mając w istocie na myśli takie fenomeny, jak: wiedza, świadomość, wyobraźnia, doświadczenie, tradycja, mitologia, legendarium, imaginarium itp. To właśnie do językoznawców należy stworzenie adekwatnego metajęzyka mówienia o pamięci; innymi słowy, widzę potrzebę odpowiedzi na pytanie, jakie są zakresy pojęciowe takich wyrazów, jak wspomniane: pamięć, wiedza, doświadczenie, tradycja, świadomość, samoświadomość etc., ustalenia, gdzie się te zakresy krzyżują (i w czym), a gdzie i w czym są rozłączne. Szczególnie istotna wydaje mi się odpowiedź na pytanie o relacje między pamięcią i wiedzą, czyli kwestia, jak to jest „wiedzieć”, a jak to jest „pamiętać” ${ }^{14}$ (zwłaszcza odnośnie do jednych i tych samych obszarów doświadczenia).

7. Siódmy z proponowanych tu obszarów dotyczy mechanizmów i sposobów oddziaływania na pamięć zbiorową poprzez język w jednym z jego szczególnych przejawów, jakim są dyskursy. Bezpośrednim impulsem do wyodrębnienia tego obszaru stał się dla mnie artykuł Marka Zaleskiego Natręctwo niepamięci naszej o Zagładzie (2016), w którym dowodził on, że dyskurs jest „instrumentem wprowadzania zmian w społecznej pamięci”, pisząc nawet o „leczeniu [pamięci] przez dyskurs publiczny”, i to w sytuacji „odrzucenia [dziś w Polsce] dyskursu jako płaszczyzny uzgadnia-

14 Pytanie to słyszę w podtekście spostrzeżeń Włodzimierza Borodzieja, który zanotował: „Niepokoję się, gdy widzę, że dziś w Polsce wielu ludziom myli się zwrot "poznajemy historię « zojęciem "pamiętamy«. Nastolatki "pamiętają" powstanie warszawskie, mają to wypisane na koszulkach, "pamiętają" »żołnierzy wyklętych". Mam wtedy ochotę zapytać: co mianowicie - tak konkretnie - pamiętacie? [...] Niebezpieczeństwo polega na tym, że skoro już »pamiętamy«, to po co mielibyśmy się czegokolwiek dowiadywać? To powszechne "pamiętanie« powstania to banalizacja czegoś ważnego. Podczepianie się pod cnoty walki o wolność. Skoro "pamiętamy«, jesteśmy lepsi moralnie, niezależnie od tego, kim naprawdę jesteśmy" (Szyłło 2018). 
nia perspektyw i argumentacji” (ibid.: 102-103). Słowa Zaleskiego wpadają w rezonans z koncepcją istniejącą w psychologii osobniczej: koncepcją metapamięci, którą w jednej z prac ze sfery indywidualnej przeniosłem do wspólnotowej, tworząc pojęcie metapamięci zbiorowej (Chlebda 2015). Metapamięć to nie tyle jakiś nowy rodzaj pamięci, ile szczególny rodzaj wiedzy (ściślej - samowiedzy): to introspekcyjna wiedza o systemie swojej pamięci, o możliwościach i sposobach zapamiętywania i wydobywania informacji z pamięci, o warunkach determinujących jej efektywność, co razem tworzy system czynników wspomagających efektywne działania poznawcze i wchodzi w zakres metapoznania - w moim ujęciu na poziomie nie tylko osobniczym, ale także wspólnotowym. To jednocześnie składowa tzw. pedagogiki pamięci, ale myśl Zaleskiego, że to dyskurs jest „instrumentem wprowadzania zmian w społecznej pamięci”, wprowadza całe to złożone i ważne społecznie zagadnienie w krąg zainteresowań także językoznawców, a nie tylko pedagogów i psychologów społecznych.

8. Ósmy obszar zagadnień dotyczy pytań o udział języka w budowie społecznych konstruktów interpretujących obiektywną rzeczywistość. Zgodnie z głównym tematem niniejszego szkicu do konstruktów takich zaliczymy w pierwszym rzędzie pamięć zbiorową, ale nie jest to konstrukt jedyny. Cały dorobek etnolingwistyki polskiej w wydaniu lubelskim podsuwa tu na myśl konstrukt zwany ,językowym obrazem świata", obok lokuje się wspominana przed chwilą wiedza, a w jej ramach zwłaszcza historiografia i przywoływana tu już archeologia teoretyczna, konkurentką jest też literatura i, szerzej, sztuka, wreszcie obraz świata tworzony przez dzisiejsze media ${ }^{15}$. Każdy z tych konstruktów ma swoją specyfikę, inny mechanizm powstawania, inny sposób postrzegania i ujmowania rzeczywistości, wszystkie jednak łączy pewien złożony wspólny mianownik składający się co najmniej z pięciu cech: wszystkie te konstrukty są względem tzw. obiektywnej rzeczywistości 1. podmiotowe, 2. selektywne, 3. interpretujące, 4. ujęzykowione i 5. narracyjne. Istnienie tego wspólnego mianownika pozwala owe konstrukty z sobą zestawiać i porównywać. Wydaje się zadaniem społecznie doniosłym porównanie takich konstruktów z sobą, zwłaszcza odnośnie do jednego i tego samego wycinka rzeczywistości, oraz określenie sfer zbieżności i rozbieżności pomiędzy otrzymanymi obrazami ${ }^{16}$.

15 Niewielka objętościowo monografia Anny Ziębińskiej-Witek (2005) zawiera próbę skrótowych prezentacji sposobów, w jaki Holocaust obrazowany jest przez historiografię, literaturę (w tym komiks) i film. Szczególny aspekt Holocaustu (rolę Polaków w jego realizacji) w pryzmatach filmu i literatury (w tym eseju i dramatu) przedstawia w Wielkim retuszu Tomasz Żukowski (2018). W Kulturze pamięci A. Erll (2018) prezentuje trzy wielkie pryzmaty postrzegania i obrazowania pamięci: wiedzę (wielodyscyplinarną), media i literaturę. Język jest w tych analizach postrzegany niemal wyłącznie jako tworzywo literatury.

16 Można sobie zatem wyobrazić np. konfrontację obrazów [Grunwaldu], [Krzyżaków], [Westerplatte] czy [Śląska] w polskiej (ale też niemieckiej!) pamięci zbiorowej, w językowym obrazie świata, w historiografii, wreszcie w literaturze i filmie. Odnośnie do tych pojęć częściową konfrontację 
Podobnie jak etnolingwistyka nie rekonstruuje całego JOS naraz, tylko postępuje krok po kroku, budując definicjami kognitywnymi obrazy poszczególnych obiektów składowych rzeczywistości, tak też pamięcioznawstwo nie odtworzy naraz całego konstruktu „polska pamięć zbiorowa”, tylko musi postępować krok po kroku, obiekt po obiekcie. Jedną z dróg poznania zawartości (polskiej) pamięci zbiorowej poprzez dane językowe - zarówno składu jej treści, jak i jej układu - jest procedura, którą naszkicowałem niegdyś właśnie w łonie etnolingwistyki, a którą nazywam mapowaniem (kartografowaniem) pamięci z wykorzystaniem jej językowych znaków oporowych: nazw, zwłaszcza własnych (Chlebda 2014). Drogami komplementarnymi wobec mapowania są koncepcja topiki Zagłady Sławomira Buryły (2012), koncepcja mnemotopiki polskiej Stefana Bednarka (2012), a także prace rekonstruujące polskie miejsca pamięci w ujęciu polsko-niemieckim, wydane pod redakcją Roberta Traby i Hansa Henninga Hahna (2012-2016).

9. Dziewiąty krąg zagadnień jest organicznie związany z ósmym, a nawet powinien działania wynikające z kręgu ósmego chronologicznie wyprzedzać. Istotą koncepcji mapowania pamięci zbiorowej jest bowiem nie tylko samo wyodrębnianie miejsc dla map mentalnych relewantnych oraz ustalanie ich nośników werbalnych, ale, i to w pierwszym rzędzie, ich kodyfikacja. Nie ma lepszego sposobu kodyfikowania „znaków oporowych" pamięci niż ich zebranie w jednym miejscu i opisanie w jednych i tych samych kategoriach, zapewniających ich porównywalność. Taką kategorię opisową upatruję w definicji - nie taksonomicznej jednak, bezradnej wobec złożonych treści znaków oporowych pamięci, ale kognitywnej, wielofasetowej, czy to w jej wersji klasycznej, przedłożonej przez Jerzego Bartmińskiego (1988; zob. też Niebrzegowska-Bartmińska 2018), czy w zaproponowanym przeze mnie wariancie półotwartej definicji syntetycznej (Chlebda 2016). Leksykografia standardowa, próbując się zmierzyć z takim zadaniem, musiałaby przełamać swój nieprzezwyciężalny, jak się wydaje, opór wobec definiowania znaczeń nazw własnych, które należą do podstawowych znaków oporowych map polskiej pamięci zbiorowej, a które przez słowniki standardowe są niemal całkowicie pomijane ${ }^{17}$.

10. I wreszcie zagadnienie dziesiąte, niejako sumujące wszystkie poprzednie. Były one w swych realizacjach związane, co podkreślałem tu wprost, zawsze z jed-

polsko-niemiecką przeprowadzono w trzech pierwszych tomach składających się na pracę Traba, Hahn 2012-2016.

17 Mam na myśli obecność nazw własnych i ich regularne definiowanie w słownikach ogólnych (nazwanych tu też standardowymi), a nie w specjalnych opracowaniach (niekiedy o charakterze leksykograficznym), które w ostatnich latach wypracowują sposoby eksplikowania znaczeń złożonych konceptów oznakowywanych nazwami własnymi lub dostarczają dla takich eksplikacji niezbędnych danych; w tym kontekście zob. m.in. prace: Bartmiński 2006 (nazwy Warszawa, Kraków, Częstochowa, Gdańsk, Lwów, Wisła, Europa, Polak, Żyd i in.), Chlebda 2006 i 2007 a (nazwy Janosik i Rejtan), Chlebda 2018b (nazwa Europa w kilkunastu językach), Puzynina 1995 (nazwa Katyń), Forecki 2018 (nazwa Jedwabne). 
nym wybranym językiem etnicznym (jako językiem pamięci i językiem mówienia o pamięci). Jednak pojawienie się Polsko-niemieckich miejsc pamięci stawia zasadne pytanie o inne języki etniczne jako języki innych pamięci wspólnotowych, to zaś rodzi kolejne pytanie o miejsca wspólne (i miejsca rozbieżne) co najmniej dwóch języków/pamięci etnicznych, a w dalszej konsekwencji - o pamięć ponadnarodową. W pamięcioznawstwie większość rozważań odnosi się do pamięci narodowej lub do pamięci wspólnotowych zamkniętych ramami narodu. Gdybyśmy dysponowali mapami pamięci w wymiarze kilku języków etnicznych, zasadne byłoby stawianie pytania, czy istnieje zbiorowa pamięć ponadnarodowa, np. pamięć słowiańska lub pamięć europejska - pamięć, którą tworzyłyby miejsca wspólne pamięci narodowych. W tym samym kierunku zmierza, jak się wydaje, Astrid Erll, która pisze:

[...] badacze zajmowali się wtedy [w latach 80.-90. XX w.] pamięciami (na ogół narodowymi) ob ok siebie. Obecnie zaś czynimy to coraz częściej ws póln ie, z transnarodowej perspektywy. Nowe pytania adresowane do kultur pamięci współczesnych społeczeństw brzmią: Jak Polacy i Niemcy mogą dialogicznie pamiętać II wojnę światową? Jak może funkcjonować pamięć wielokier un kowa, np. jed noczesne upamiętnianie niewolnictwa i Holocaustu? (Erll 2018: 8).

To jest sprawa najwyższej relewancji społecznej, jeśli mieć na uwadze potrzebę tworzenia np. polsko-niemieckich czy polsko-rosyjskich podręczników historii lub zagadnienia integracji europejskiej na różnych szczeblach i płaszczyznach. Tu właśnie pamięcioznawstwo i etnolingwistyka mogą podać sobie ręce w sposób wybitnie twórczy i efektywny.

Wszystko to, co powiedziałem wyżej o pamięci i o związkach pamięci z językiem, odnoszę także do niepamięci. Mimo owego negującego nie- w strukturze wyrazu niepamięć nie jest jakimś niebytem czy bytem zaprzeczonym: jest bytem realnym, przestrzenią gęsto wypełnioną obiektami z pamięci wypchniętymi bądź do niej niedopuszczonymi. Obiekty te muszą mieć swoje nazwy, jest więc niepamięć ujęzykowiona tak, jak ujęzykowiona jest pamięć. Skoro tak, możliwe jest mapowanie także niepamięci - lub, powiedzmy wprost, mapowaniu powinna podlegać cała pamięć/niepamięć danego miejsca i czasu. Jeśli mapowanie takie ma przybliżać treść danej tożsamości etniczno-kulturowej, mapowanie niepamięci jest nie tylko tak samo istotne, jak mapowanie pamięci: jest wręcz istotniejsze, bo poznanie tego, co Polacy ze swej pamięci zbiorowej wypchnęli lub czego do niej nie dopuścili, rzuca światło na składowe tożsamości niejawne, skrywane, wstydliwe, traumatyczne, konieczne jednak dla obrazu całości (Chlebda 2007b). Językoznawstwo zabrało w tej sprawie głos, ale na razie tylko na poziomie nielicznych i ogólnych deklaracji. 


\section{Literatura}

Apresjan Ju.D., 1994, Naiwny obraz świata a leksykografia, tłum. A. Pajdzińska, „Etnolingwistyka" 6, s. 5-12.

Bartmiński J., 1988, Definicja kognitywna jako narzędzie opisu konotacji słowa, [w:] idem (red.), Konotacja, Lublin, s. 169-185.

BARTMIŃski J. (red.), 2006, Język - wartości - polityka. Zmiany rozumienia nazw wartości $w$ okresie transformacji ustrojowej $w$ Polsce. Raport z badań empirycznych, Lublin.

BARTMIŃsKi J., CHLEBDA W., 2008, Jak badać językowo-kulturowy obrazświata Słowian i ich sąsiadów?, „Etnolingwistyka” 20, s. 11-27.

Bednarek S., 2012, Mnemotopika polska, [w:] J. Adamowski, M. Wójcicka (red.), Pamięć jako kategoria rzeczywistości kulturowej, Lublin, s. 33-46.

BuryŁa S., 2012, Topika Holokaustu. Wstępne rozeznanie, „Świat Tekstów. Rocznik Słupski” 10, s. 131-151.

Burzyńska A., Markowski M.P., 2006, Teorie literatury XX wieku. Podręcznik, Kraków. Chlebda W., 1997, Zarys polskiej geografii mentalnej, „Przegląd Humanistyczny” 3, s. 81-94. Chlebda W., 2002, Polak przed mentalna mapa świata, „Etnolingwistyka” 14, s. 9-26.

Chlebda W., 2006, Janosik: od mitu do eponimu, „Studia i Szkice Slawistyczne” 7, s. 181-192.

Chlebda W., 2007a, Tadeusza Rejtana los pośmiertny w polszczyźnie, [w:] E. Dąbrowska, K. Kosakowska-Jarosz (red.), Teksty - konteksty - interpretacje. W kręgu literatury, języka i kultury, Opole, s. 153-168.

Chlebda W., 2007b, Tezy o niepamięci zbiorowej, „Prace Filologiczne” LIII, s. 71-78.

Chlebda W., 2010, W poszukiwaniu jezzykowo-kulturowego obrazu świata Słowian, [w:] idem (red.), Etnolingwistyka a leksykografia. Tom poświęcony Profesorowi Jerzemu Bartmińskiemu, Opole, s. 7-20.

Chlebda W., 2011, Szkice do językowego obrazu pamięci. Pamięć jako wartość, „Etnolingwistyka" 23, s. 83-98.

Chlebda W., 2012a, Czy polska etnolingwistyka może być zwornikiem nauk humanistycznych?, [w:] M. Grochowski (red.), Językoznawstwo w Polsce. Kierunki badań i perspektywy rozwoju. Materiały z sesji jubileuszowej Komitetu Językoznawstwa PAN, Warszawa, s. 91-98.

Chlebda W., 2012b, Pamięć ujęzykowiona, [w:] J. Adamowski, M. Wójcicka (red.), Pamięć jako kategoria rzeczywistości kulturowej, Lublin, s. 109-119.

Chlebda W., 2014, O potrzebie mapowania polskiej pamięci/niepamięci zbiorowej, [w:] E. Golachowska, A. Zielińska (red.), Konstrukcje i destrukcje tożsamości, t. 3: Narracja i pamięć, Warszawa, s. 39-47.

Chlebda W., 2015, Pogranicza i pograniczność w polskich perspektywach ogladu, [w:] idem, I. Dobrotová (red.), Pograniczność i pogranicza w perspektywie nauk społecznych i humanistycznych, Opole, s. 43-77.

ChlebDA W., 2016, W stronę optymalizacji słownikowego objaśniania znaczeń, „Stylistyka” XXV, s. 319-335.

Chlebda W., 2018a, Pamięć i język. Zarys relacji, [w:] W. Czachur (red.), Pamięć w ujęciu lingwistycznym. Zagadnienia teoretyczne i metodyczne, Warszawa, s. 56-67.

CHLebDA W. (red.), 2018b, Leksykon aksjologiczny Słowian i ich sąsiadów, red. J. Bartmiński, t. 2: Europa, Opole - Lublin.

Chlebda W., 2019, Jak historia odkłada się w pamięci, jak pamięć odkłada się w języku, „Etnolingwistyka” 31, s. 55-72. 
Chlebda W., w druku, Z katalogu zadań pamięcioznawczych, „Stylistyka” XXVIII.

Czachur W. (red.), 2018, Pamięć w ujęciu lingwistycznym. Zagadnienia teoretyczne i metodyczne, Warszawa.

Czerwiński M., 2015, Kultura, dyskurs, znak, Kraków.

ĆWIeK-Rogalska K., 2017, Zapamiętane w krajobrazie. Krajobraz kulturowy czesko-niemieckiego pogranicza w czasach przemian, Warszawa.

Erll A., 2018, Kultura pamięci. Wprowadzenie, tłum. A. Teperek, Warszawa.

Fabiszak M., Brzezińska A.W., 2018, Cmentarz, park, podwórko. Poznańskie przestrzenie pamięci, Warszawa.

Fabiszak M., Brzezińska A.W., Owsıński M. (red.), 2016, Znaki (nie)pamięci. Teoria i praktyka upamiętniania w Polsce, Kraków.

Forecki P., 2018, Po Jedwabnem. Anatomia pamięci funkcjonalnej, Warszawa.

GŁowıŃski M., 1995, Pismak 1863 i inne szkice o różnych brzydkich rzeczach, Warszawa.

Janicka E., Żukowski T., 2016, Przemoc filosemicka? Nowe polskie narracje o Żydach po roku 20oo, Warszawa.

Kończal K., Wawrzyniak J., 2011, Polskie badania pamięcioznawcze: tradycje, koncepcje, (nie)ciagłości, „Kultura i Społeczeństwo” nr 4, s. 11-63.

Leder A., 2014, Prześniona rewolucja. Ćwiczenie z logiki historycznej, Warszawa.

MaćKiewiCz J., 1999, Słowo o słowie. Potoczna wiedza o języku, Gdańsk.

Marciniak A., 2012, Przedstawianie i narratywizm $w$ archeologii, [w:] S. Tabaczyński, A. Marciniak, D. Cyngot, A. Zalewska (red.), Przeszłość społeczna. Próba konceptualizacji, Poznań, s. 162-177.

MarCZewska M., 2012, „Ja cię zamawiam, ja cię wypędzam...”. Choroba. Studium językowo-kulturowe, Kielce.

NiEBRZEGowSKA-BARTMIŃsKA S., 2017, Jakie dane są relewantne etnolingwistycznie?, „Etnolingwistyka" 29, s. 11-29, [on-line:] http://dx.doi.org/10.17951/et.2017.29.11.

NiebrzegowsKa-BARTMiŃsKa S., 2018, O różnych wariantach definicji leksykograficznej od taksonomii do kognitywizmu, „Etnolingwistyka” 30, s. 259-284, [on-line:] http:// dx.doi.org/10.17951/et.2018.30.259.

Niewiara A., 2009, Kształty polskiej tożsamości. Potoczny dyskurs narodowy w perspektywie etnolingwistycznej (XVI-XX w.), Katowice.

Nija Kowski L.M., 2006, Domeny symboliczne. Konflikty narodowe $i$ etniczne w wymiarze symbolicznym, Warszawa.

Orliński W., Libeskind D., 2018, Stacje metra World Trade Center zaprojektowałem dla moich rodziców: drukarza i szwaczki, „Gazeta Wyborcza. Duży Format” 13 VIII, [on-line:] http://wyborcza.pl/duzyformat/7,127290,23773922,daniel-libeskind-stacje-metraworld-trade-center.html (dostęp: $15 \mathrm{~V}$ 2019).

Pajdzińska A., 2004, Niepamięć - córka niedbalstwa?, [w:] J. Liberek (red.), Studia nad polszczyzna współczesna i historyczną. Prace dedykowane Profesorowi Stanisławowi Bąbie w 65-lecie urodzin, Poznań, s. 229-236.

Pajdzińska A., 2007, Pamięć jako wartość, [w:] J. Mazur, A. Małyska, K. Sobstyl (red.), Człowiek wobec wyzwań współczesności. Upadek wartości czy walka o wartość?, Lublin, S. 253-261.

Pajdzin'ska A., 2005, Obraz pamâti v pol'skom âzyke, [w:] T. Dobrzynska, R. Kuncheva (red.), Memory and Text. Cognitive and Cultural Aspects. Pamât' i tekst. Kognitivnye i kul'turologičeskie aspekty, Sofia, s. 189-200. 
Pomian K., 2006, Historia - nauka wobec pamięci, Lublin.

Puzynina J., 1995, Katyń: słowo-symbol, „Więź” nr 6, s. 25-35.

Saryusz-Wolska M., Traba R. (red.), 2014, Modi memoranda. Leksykon kultury pamięci, Warszawa.

SzyŁŁo A., 2018, Dwie godziny na barykadzie, „Gazeta Wyborcza. Duży Format” 29 IX, [on-line:] http://wyborcza.pl/duzyformat/1,127290,20758034,dwie-godziny-na-barykadzielekcje-historii-w-szkole.html (dostęp: $15 \mathrm{~V}$ 2019).

Tabaczyński S., Marciniak A., Cyngot D., Zalewska A. (red.), 2012, Przeszłość społeczna. Próba konceptualizacji, Poznań.

Traba R., Hahn H.H. (red.), 2012-2016, Polsko-niemieckie miejsca pamięci, t. 1-4, współpr. M. Górny, K. Kończal, Warszawa.

WAsilewski J., 2012, Opowieści o Polsce. Retoryka narracji, Warszawa.

WĘŻYK K., NAPIóR KOWSKi M., 2016, Woje wyklęci spod Smoleńska. Jak uporać się z pamięcia narodową, „Gazeta Wyborcza” 6 VIII, s. 18-19.

WójCicka M., 2014, Pamięć zbiorowa a tekst ustny, Lublin.

WójCicKa M., w druku, Gatunek pamięci zbiorowej. Rekonesans, „Stylistyka” XXVIII.

Zaleski M., 2016, Natręctwo niepamięci naszej o Zagładzie, „Teksty Drugie” nr 6, s. 90-105, [on-line:] http://dx.doi.org/10.18318/td.2016.6.7.

ZiĘBińsKA-Witek A., 2005, Holocaust. Problemy przedstawiania, Lublin.

Żukowski T., 2018, Wielki retusz. Jak zapomnieliśmy, że Polacy zabijali Żydów, Warszawa.

\section{On the Challenges and Tasks of Linguistic Memory Research Summary}

The paper summarizes the first stage of development of a new subfield of linguistics known as linguistic memory research, and poses three questions which are important for its further development: what are the mutual relations and tangents between language and memory (both individual and collective), what are the mutual relations between linguistic memory research and the related field of cognitive ethnolinguistics (as well as such disciplines in humanities as historiography and theoretical archaeology), and lastly, in what areas can linguistic memory research and ethnolinguistics support each other most effectively. A greater part of the paper is devoted to a brief overview of the ten problem areas in memory research, and a presentation of specific tasks posed before linguists by questions concentrated in those areas: from the determination of the role of memory in the processes of lexicalization and phraseologization, through the classification of verbal (phonic, lexical, phraseological, syntactic, genre-related, etc.) exponents of memory, and the determination of their role in the learning of aspects of individual and collective memory, up to an analysis of the role of the given ethnic language in the building of large mental constructs interepreting the reality, such as collective memory, linguistic image of the world, and community knowledge. 